
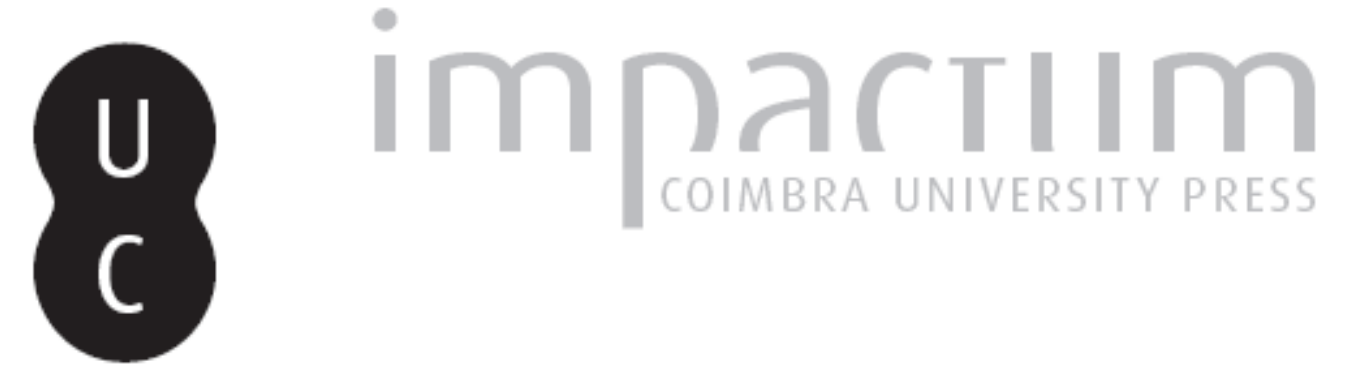

\title{
Os Borges de Carvalhais, Senhores de Ferreiros, Avelãs de Cima e Ílhavo
}

\section{Autor(es): Lopes, Luís Seabra}

Publicado por: Imprensa da Universidade de Coimbra

URL persistente:

URl:http://hdl.handle.net/10316.2/43329

DOI:

DOI:https://doi.org/10.14195/1645-2259_17_5

Accessed : $\quad$ 26-Apr-2023 14:10:00

A navegação consulta e descarregamento dos títulos inseridos nas Bibliotecas Digitais UC Digitalis, UC Pombalina e UC Impactum, pressupõem a aceitação plena e sem reservas dos Termos e Condições de Uso destas Bibliotecas Digitais, disponíveis em https://digitalis.uc.pt/pt-pt/termos.

Conforme exposto nos referidos Termos e Condições de Uso, o descarregamento de títulos de acesso restrito requer uma licença válida de autorização devendo o utilizador aceder ao(s) documento(s) a partir de um endereço de IP da instituição detentora da supramencionada licença.

Ao utilizador é apenas permitido o descarregamento para uso pessoal, pelo que o emprego do(s) título(s) descarregado(s) para outro fim, designadamente comercial, carece de autorização do respetivo autor ou editor da obra.

Na medida em que todas as obras da UC Digitalis se encontram protegidas pelo Código do Direito de Autor e Direitos Conexos e demais legislação aplicável, toda a cópia, parcial ou total, deste documento, nos casos em que é legalmente admitida, deverá conter ou fazer-se acompanhar por este aviso.

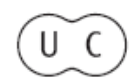




\section{Os Borges de Carvalhais, Senhores de Ferreiros, Avelãs de Cima e Ílhavo}

\section{The Borges of Carvalhais, Lords of Ferreiros, Avelãs de Cima and Ílhavo}

\section{Luís SEABRa Lopes}

Professor Associado, Universidade de Aveiro lsl@ua.pt

Texto recebido em/Text submitted on: 21/11/2016 Texto aprovado em /Text approved on: 23/04/2017

Resumo: O vasto domínio senhorial frequentemente referido como "senhorio de Carvalhais" esteve na posse dos Borges e de seus descendentes desde meados do século XV até à reforma liberal. Abrangia os antigos concelhos de Ferreiros, Avelãs de Cima e Ílhavo, no distrito de Aveiro. Não existem estudos aprofundados sobre a história deste senhorio. A própria série cronológica dos chamados "senhores de Carvalhais" só é bem conhecida a partir de António Borges de Miranda, $3^{\circ}$ senhor de Carvalhais na linha dos Borges, indivíduo nascido por volta de 1470. Neste artigo, a série dos senhores de Carvalhais na linhagem Borges é identificada e enquadrada no contexto histórico dos séculos XV e XVI.

Palavras-chave: nobreza; domínios senhoriais; genealogia; senhorio de Carvalhais; família Borges.

Abstract: The vast seigniorial domain of Carvalhais was held by the Borges family and descendants from the mid-fifteenth century until the liberal reform. It integrated the old counties of Ferreiros, Avelãs de Cima and Ílhavo, in the modern district of Aveiro. There are no in-depth studies on the history of this seigniorie. The chronological series of the so-called "lords of Carvalhais" is only well known from António Borges de Miranda, 3rd lord of Carvalhais in the Borges line, an individual born around 1470. In this article, the series of lords of Carvalhais in the Borges lineage is studied in the historical context of the 15th and 16th centuries.

Keywords: nobility; seigniories; genealogy; seigniorie of Carvalhais; Borges family.

\section{Introdução}

Quem passa por Carvalhais (f. Moita, c. Anadia), não deixará de reparar num edifício nobre de dois pisos, dos séculos XVII-XVIII, cuja origem quase caiu no esquecimento. Trata-se do antigo paço dos senhores da terra (Silveira 1910-1911). Serviu de residência aos ouvidores do senhorio de Carvalhais e, pontualmente, aos próprios senhores da terra (Lopes 2016). Um edifício com essa função documenta-se já no foral manuelino de Ferreiros, c. Anadia, a propósito de um casal localizado em Carvalhais e "que se chamaua do paço" (Madahil 
1942). O antigo concelho de Ferreiros teve foral dado por Dom Sancho I em 1210, sendo por isso um dos mais antigos de todo o distrito de Aveiro (Santos 1993). O paço de Carvalhais era, no entanto, a cabeça de um domínio senhorial mais vasto, que abrangia, não só o concelho de Ferreiros, mas também os antigos concelhos de Avelãs de Cima e Ílhavo.

Não existem estudos aprofundados sobre a história deste senhorio. A própria série cronológica dos chamados "senhores de Carvalhais" só é bem conhecida a partir de António Borges de Miranda, $3^{\circ}$ senhor de Carvalhais na linha dos Borges. O presente artigo identifica a série dos senhores de Carvalhais na linhagem Borges enquadrando-a no contexto histórico da época. $O$ tratamento dado a esta família senhorial na literatura disponível é analisado na secção II. A secção III reúne alguma informação essencial sobre a formação do senhorio de Carvalhais e os senhores que teve a partir de meados do século XIV. A série dos senhores de Carvalhais na linhagem Borges é estudada na secção IV. Finalmente, as origens e ascensão da família e o seu percurso até finais do século XVI são estudados na secção $\mathrm{V}$.

Fig. 1.

Paço de Carvalhais, dos senhores de

Ferreiros, Avelãs de

Cima e Ílhavo

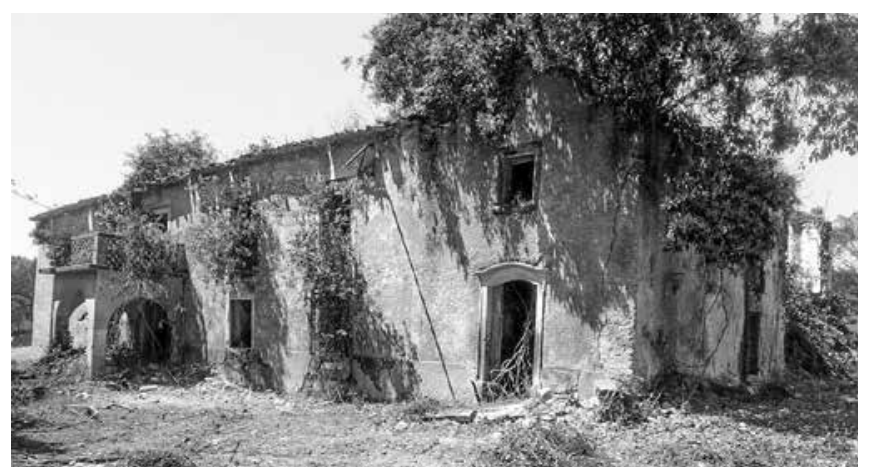

\section{Uma nota historiográfica}

Nesta secção, são analisados e desmontados vários equívocos que têm circulado sobre os Borges de Carvalhais. A Tabela I sistematiza as principais hipóteses historiográficas sobre a ascendência de António Borges de Miranda, senhor de Carvalhais no início do século XVI.

Alguns autores identificam António Borges de Miranda com um António Borges, natural de Lisboa, filho de Duarte Borges e neto de Pedro Borges (Madahil 1922: 1819; Fonseca 2007: 58). Contudo, esta hipótese de filiação baseia-se na informação de duas cartas de brasão de armas concedidas a esse António Borges, uma em 1535 ( $A H G$ n. ${ }^{\circ}$ 118: p. 32) e outra em 1550 (Borrego 2003, n. 49: 34-35). Ora, como António Borges de Miranda morreu em 1529, o António Borges das cartas de armas é necessariamente outro. Madahil (1922: 
21, nota; 1938: 184) prometia aprofundar a genealogia dos Borges, mas parece que nunca chegou a fazê-lo.

Os restantes trabalhos são nobiliários tardios ou estudos mais recentes que, para a matéria em análise, se reportam a nobiliários. O nobiliário mais antigo é da segunda metade do século XVII, cerca de século e meio após a morte de António Borges de Miranda, e dois séculos depois de ter morrido o primeiro Borges de Carvalhais. Os nobiliários elaborados numa época mais próxima dos factos nada adiantam sobre a filiação de António Borges de Miranda (Góis 1560; LLS16; LLRP).

A hipótese dominante na Tabela I, segundo a qual António Borges de Miranda seria filho de um Gonçalo Borges, é correcta. Documentalmente, prova-se que Gonçalo Borges foi legitimado em 1463 (e não em 1439), porteiro-mor e senhor de Carvalhais por doação de 1464.

Tabela I. Hipóteses historiográficas sobre a ascendência de António Borges de Miranda, $3^{\circ}$ senhor de Carvalhais na linha dos Borges

\begin{tabular}{|c|c|c|c|}
\hline & Pai & Avô & Bisavô \\
\hline A & $\begin{array}{l}\text { Gonçalo Borges, senhor de } \\
\text { Carvalhais, porteiro-mor }\end{array}$ & Duarte Borges & $\begin{array}{c}\text { Diogo Borges, } \\
\text { senhor de Gestaçô }\end{array}$ \\
\hline B & $\begin{array}{l}\text { Gonçalo Borges, senhor de } \\
\text { Carvalhais, porteiro-mor }\end{array}$ & $\begin{array}{c}\text { Duarte Borges, camareiro } \\
\text { de Dom Duarte }\end{array}$ & $\begin{array}{c}\text { Diogo Gonçalves Borges, } \\
\text { senhor de Ourilhe, etc. }\end{array}$ \\
\hline $\mathrm{C}$ & $\begin{array}{l}\text { Gonçalo Borges, senhor de } \\
\text { Carvalhais, porteiro-mor }\end{array}$ & $\begin{array}{c}\text { Duarte Borges, } \\
\text { camareiro-mor de Dom } \\
\text { Duarte }\end{array}$ & \\
\hline $\mathrm{D}$ & $\begin{array}{c}\text { Gonçalo Borges, da } \\
\text { Arruda, legitimado em } \\
1439, \\
\text { senhor de Carvalhais }\end{array}$ & $\begin{array}{c}\text { Rui Borges, } \\
\text { camareiro-mor (D. } \\
\text { Duarte) e } \\
\text { porteiro-mor (D. Afonso } \\
\text { V) }\end{array}$ & Diogo Borges \\
\hline $\mathrm{E}$ & $\begin{array}{c}\text { Gonçalo Borges, } \\
\text { senhor de Carvalhais por } \\
\text { doação de } 1464\end{array}$ & $\begin{array}{l}\text { Rui Dias Borges, } \\
\text { senhor de Carvalhais }\end{array}$ & $\begin{array}{l}\text { Diogo Gonçalves Borges, } \\
\text { senhor de Ourilhe, etc. }\end{array}$ \\
\hline $\mathrm{F}$ & $\begin{array}{l}\text { Gonçalo Borges, senhor de } \\
\text { Carvalhais por doação de } \\
\text { 1464, porteiro-mor }\end{array}$ & $\begin{array}{l}\text { Rui Borges, senhor } \\
\text { de Carvalhais }\end{array}$ & $\begin{array}{c}\text { Diogo Borges, comenda- } \\
\text { dor do Torrão, senhor de } \\
\text { Gestaçô }\end{array}$ \\
\hline G & Duarte Borges & Pedro Borges & \\
\hline $\mathrm{H}$ & $\begin{array}{l}\text { Gonçalo Borges, senhor de } \\
\text { Carvalhais, porteiro-mor }\end{array}$ & $\begin{array}{l}\text { Rui Borges de Sousa, } \\
\text { alcaide-mor de Santarém, } \\
\text { senhor de Carvalhais }\end{array}$ & $\begin{array}{c}\text { Rui Borges, } \\
\text { alcaide-mor de Santarém, } \\
\text { senhor de Carvalhais }\end{array}$ \\
\hline
\end{tabular}

(A) Alão <1693, III, 1: 176-177; (B) Silva <1705, tit. "Borges", \$1, n.o 4-6; (C) Guerra 1965: 328, 350 e 410; (D) Alão <1693, V, 1: 25-26; (E) Gayo <1831, VII, tit. "Borges", $\$ 1$, n. ${ }^{\circ} 6$, e $\$ 30$, n. ${ }^{\circ} 7-8$; (F) Gayo <1831, I, tit. “Andrades Freires”, §50, n.o 46; (G) Madahil 1922: 1819, e Fonseca 2007: 58; (H) Soveral 2004, II: 349-352. 
Sobre o avô de António Borges de Miranda, os autores são bastante menos concordantes. Segundo uns, António Borges seria neto de um Duarte Borges, camareiro-mor de Dom Duarte. Segundo outros, seria neto de um Rui Borges, mas a caracterização deste Rui Borges varia bastante de autor para autor. Ora, pela doação do senhorio de Carvalhais a Gonçalo Borges, confirma-se que este era de facto filho de um Rui Borges, também senhor de Carvalhais. Averigua-se documentalmente que este Rui Borges foi almoxarife da alfândega de Lisboa e cavaleiro do Conselho d'el Rei Dom Afonso V.

Gayo conhecia a doação de 1464 e cita-a correctamente. No entanto, identifica aquele Rui Borges, senhor de Carvalhais, com um Rui Dias Borges, filho de Diogo Gonçalves Borges (Tabela I, hipótese E), e atribui-lhe seis filhos. Ora, como a doação declara que Gonçalo Borges era o único filho de seu pai, tudo leva a crer que o autor terá confundido o senhor de Carvalhais com um homónimo. Ao tratar de outra família, Gayo dá outra versão. Aí diz que Rui Borges, senhor de Carvalhais, teria sido filho de Diogo Borges, comendador do Torrão, e de sua mulher Genebra de Andrade (Tabela I, hipótese F), atribuindo-lhe os mesmos seis filhos que tinha dado ao Rui Dias Borges. No entanto, infere-se da documentação que aquele Diogo Borges e sua mulher não tiveram filhos, portanto o $1^{\circ}$ senhor de Carvalhais não era filho desse casal ${ }^{1}$.

Estas breves indicações dão uma ideia da fiabilidade de nobiliários elaborados vários séculos após os factos, com pouco acesso a fontes primárias, e com muita imaginação à mistura. A maior parte dos nobiliários transmitem informação de teor lendário que tem que ser usada com extrema precaução.

Numa obra recente, em que encontramos um capítulo sobre os Borges, o autor combinou informações dos nobiliários com informações colhidas nas chancelarias régias, etc. (Soveral 2004, II: 343-363). A citação frequente dos documentos coevos dá uma aparência de solidez mas, quando analisamos as propostas em pormenor, vemos que a utilização dos nobiliários e de outras fontes tardias em alguns casos prevaleceu sobre a leitura atenta dos documentos, levando a em erros desnecessários. O autor faz remontar o senhorio dos Borges a um suposto João Gonçalves Borges, não documentado, nascido por volta de 1350, que seria, nas suas palavras, senhor de "Carvalhais (Mesão Frio), Ferreiros (Tondela ou Anadia?) e do Reguengo de Quintela (Moita, Anadia?)”. No entanto, o que se documenta é que o senhorio de Carvalhais, com Ferreiros, Quintela, Avelãs de Cima, Ílhavo, etc., esteve na posse de Gil de Ocem, sucedendo-lhe o filho Martim de Ocem, e após a morte deste passou para o infante Dom Pedro.

\footnotetext{
ANTT, Ch. Afonso V, L. 23, fl. 63v; Leit. Nova, Beira, L. 1, fl. 46v-47. Ainda segundo Gayo (<1831, VII, tit. "Borges", \$6, n. 6, e XXII, tit. "Pachecos", \$2, n. ${ }^{\circ} 9$ ), também um Álvaro Borges, c.c. Isabel ou Inês de Sousa, e o filho destes, Pedro Borges da Silva, teriam sido senhores de Carvalhais. Pelo contexto, isso teria acontecido na segunda metade do século XV. Não conheço qualquer fundamento para tais afirmações e não me parecem sequer credíveis, em face do que se documenta sobre Rui Borges e seu filho.
} 
Segundo o mesmo autor, o senhorio de Carvalhais teria passado de João Gonçalves Borges para um filho, Rui Borges, e depois para um neto, Rui Borges de Sousa. Seria este último o pai de Gonçalo Borges, beneficiário da doação de 1464 referida acima. No entanto, resulta claro dessa doação e de outros documentos que Rui Borges, pai de Gonçalo Borges, ainda estava vivo em 14631464. Ora, sabemos que Rui Borges de Sousa, alcaide-mor de Santarém, morreu antes de 1462/05/17, data em que a sua herança já se encontrava em processo de partilhas ${ }^{2}$. Assim, este Rui Borges de Sousa não pode ser o pai de Gonçalo Borges, senhor de Carvalhais. O pai de Gonçalo Borges poderia ser o outro Rui Borges, suposto pai de Rui Borges de Sousa. No entanto, o autor atribui onze filhos a esse Rui Borges, o que contraria as informações da doação, segundo as quais Gonçalo Borges seria o único filho de Rui Borges.

Quanto ao pai de Rui Borges, portanto bisavô de António Borges de Miranda, os nobiliários fazem crer que terá sido um Diogo Borges, mas os detalhes variam bastante de autor para autor (Tabela I, hipóteses A a F). O assunto é abordado na secção V.1.

\section{A formação do senhorio de Carvalhais}

Em 1355/01/19, os lugares que viriam a ser incorporados no domínio dos chamados "senhores de Carvalhais" ficaram abrangidos no dote de casamento da infanta Dona Maria, neta de Dom Afonso IV, com Dom Fernando de Aragão (Provas, I, doc. 35). Em 1376/03/25, na sequência da morte de Dona Maria, as terras que esta havia recebido em dote foram doadas à infanta Dona Beatriz (ANTT, Ch. Fernando, L. 1, fl. 189v-190v).

O espaço em estudo individualizou-se pouco tempo depois, já no início do reinado de Dom João I, quando este rei o doou ao Doutor Gil de Ocem, seu conselheiro. Em 1387/11/30, o filho, Martim de Ocem, que viria a ser tesoureiro-mor do rei e chanceler-mor do infante Dom Duarte, teve confirmação de todas as terras que tinham sido de seu pai ${ }^{3}$. Em 1416/04/04, a pedido de "Martim d'Osem, do nosso conselho", Dom João I confirmou aos moradores das terras de "Auelaas de Cima e Carualhaes, que sam no julgado de Ferreiros, [... $e$ Ylhauo", o privilégio de terem o seu juiz (ver nota 7). A carta de confirmação refere que aquelas terras tinham sido "dadas a seu padre". O foral manuelino de Ferreiros, refere um casal que "o doutor Martim d'Osem [tornou] a fazer e encabescar" (Madahil 1942).

ANTT, Ch. Afonso V, L. 14, fl. 108v; já citado por Moreno, 1979-1980, II: 977. Esta incompatibilidade de datas é decisiva no sentido de diferenciar Rui Borges, senhor de Carvalhais, de Rui Borges de Sousa, alcaide-mor de Santarém. No entanto, Moreno (1979-1980, II: 741-742 e 976-977) já tinha diferenciado correctamente os dois contemporâneos com base em outros dados biográficos.

3 CPDJI, II, 1, doc. 238. Sobre os Ocem, ver Freire, 1921-1930, II: 368-400. 
No que diz respeito à transmissão hereditária do património senhorial, esta época foi de transição de um modelo de partilha equitativa para um modelo que privilegiava o filho varão primogénito (Sousa 2013). Um fenómeno relacionado é o da progressiva implantação do morgadio, ao longo dos séculos XIV e XV. Rosa (1995) estudou vários aspectos do comportamento linhagístico nesse contexto. A transmissão de ofícios burocráticos dentro das famílias é outro fenómeno que reflecte a mesma tendência (Caetano 2011: 10). A primazia dada aos varões primogénitos estabelecia uma liderança clara dentro de cada linhagem, dando-lhe maior visibilidade e prestígio. Este fenómeno de concentração do património no chefe da linhagem está na origem das grandes casas nobiliárquicas portuguesas, realidade que se torna notória no século XV. Foi também no século XV, sobretudo no início, que se registou o maior número de doações de senhorios jurisdicionais (Cunha, Monteiro 2010: 57). No caso de Ferreiros, Avelãs de Cima e Ílhavo, o novo modelo começou por ser ensaiado com os Ocem, mas a doação não passou da segunda geração devido a extinção da linhagem. De facto, Martim de Ocem morreu, sem descendência, em 1431, ou finais do ano anterior (Freire 1921-1930, II: 381).

Em 1431/01/17, já se referencia em Verdemilho um "casall do doutor Martim d'Osem que ora he do Senhor Jnfante Dom Pedro" (MA 88: 175). Poucos anos depois, Dom Duarte doou o "couto d'Avellaãs de Cima, e de Ferreiros, e do reguengo de Quintela, e d'Arcos, e dos lugares de Jlhauo e Villa de Milho, e dos casaes de Saa" a seu irmão, o infante Dom Pedro, duque de Coimbra (CPDD, I, 2, doc. 810, de 1437/02/27). A lista de lugares é mais extensa, mas o espaço é o mesmo. A doação veio ampliar o vasto território que o duque já possuía de Coimbra até Aveiro, desde o tempo de Dom João I. O foral manuelino de Avelãs de Cima refere os "tombos das ditas terras feitos pello Jmfäte Dom Pedro, sendo senhor dellas" (Madahil 1941) e o de Ferreiros refere a "jnquiriçam feita em tempo do jmfante Dom Pedro" (Madahil 1942). Com a morte de Dom Duarte, ocorrida em 1438, Dom Pedro acabaria por assumir a regência do reino em nome de Dom Afonso V, então ainda criança. Desde o início, o problema da regência dividiu o reino, acabando por conduzir à batalha de Alfarrobeira, em 1449, em que morreu o próprio infante.

Pouco tempo depois, Dom Afonso V acabaria por doar a "Ruj Borges novamente a terra de Carvalhaes, e por sua morte a Gonçalo Borges, seu filho" ("Copia das Mercês ...", Provas, II, doc. 8: 21). A palavra "novamente” certamente significa que a doação foi feita "de novo" e não por confirmação de uma doação anterior a um ascendente. Como se verá adiante, a doação ocorreu menos de um ano após a batalha de Alfarrobeira. Todo o historial posterior mostra que a designação "terra de Carvalhaes" era uma forma abreviada de identificar o senhorio que efectivamente abrangia aqueles três concelhos. A expressão tem origem no facto de o paço destes Borges ter sido levantado no lugar de Carvalhais. 
Entretanto, Dom João II, que era neto materno do infante Dom Pedro, duque de Coimbra, viria a restaurar esse ducado na pessoa do seu filho Dom Jorge de Lancastre. Para esse efeito, deixou-lhe em testamento (1495) as terras que outrora tinham sido doadas ao infante Dom Pedro, incluindo as terras do senhorio de Carvalhais (Provas, II, doc. 28, de 1495/09/29). No entanto, essas terras não estavam na posse do rei, como por vezes se supõe, mas sim na posse de Gonçalo Borges, filho de Rui Borges. O rei reconhecia que algumas das terras estavam "dadas a algumas pessoas", e por isso passariam para o filho "quando quer que vagarem”. A doação a Gonçalo Borges foi feita "em sua vida”. Por sua morte, o senhorio de Carvalhais passaria para Dom Jorge. Porém, a doação acabou por ser renovada nos descendentes até ao século XIX.

\section{Borges de Carvalhais: uma nova linhagem senhorial}

A série dos senhores de Carvalhais na linhagem Borges será agora identificada. Sendo conhecidos os erros e contradições dos antigos nobiliários, especialmente notórios no caso dos Borges, o estudo que se segue centra-se na documentação coeva, com base na qual são esclarecidos todos os aspectos essenciais. Outros aspectos do seu percurso social serão estudados na secção V.

\section{Rui Borges}

Deverá ter nascido por volta de 1400 . Foi almoxarife da alfândega de Lisboa e conselheiro régio. Em 1438/07/22, Dom Duarte doou a "Ruj Borges, cauallejro de nossa casa e almoxarife da nossa alfandega de Lisboa" uma tença anual de 150000 reais brancos, a pagar na alfândega ${ }^{4}$. Encontram-se várias outras referências à actividade de almoxarife ${ }^{5}$.

Em 1440/04/06, Dom Afonso V doou a "Rruy Borjes, nosso almoxarife da dita alfamdega" umas casas localizadas "na dita çidade [de Lisboa], na Rua da Paadaria, porta com porta do paaço dos tabeliães" (ANTT, Leit. Nova, Estrem., L. 10, fl. 80). As ditas casas tinham sido confiscadas ao "escripvam da nossa alfandega da muy nobre leall çidade de Lyxboa", Gonçalo Anes, por "cousas que fez em

\footnotetext{
ANTT, Ch. Afonso V, L. 38, fl. 3, confirmação de 1439/11/02; já citado por Moreno, 1979-1980, II: 741.

"Ruj Borges, cavalleiro da nossa casa e almoxarife que ora he da nossa alfandega desta cidade de Lixboa" ficou responsável por pagar moradia mensal de 140000 libras a um nobre (ANTT, Ch. Afonso V, L. 19, fl. 50, de 1439/02/02); pagamento de 371000 libras feito, em 1437-1439, por "Rruy Borges, almoxarife da nossa alfamdega" (Marrocos, I, doc. 131, de 1440/08/08); pagamento de 14500 reais feito, em 1439-1440, por "Rruy Borges, almoxarife que foy da nossa alfamdega da cidade de Lixboa" (Marrocos, I, doc. 132, de 1440/08/10); Pagamento de 112902 reais recebido, em 1440-1441, por "Ruy Borges, almoxarife da alfandega de Lixboa em o dito tempo" (Marrocos, I, adenda, doc. 94, de 1443/07/12); quitação a "Ruy Borjas, que foy almoxarjfe d'alfandega dessa çidade", das contas que tinha apresentado do seu almoxarifado (CPDD, II, doc. 84, de $1441 / 12 / 28)$.
} 
deserviço del Rey meu seenhor e padre”. Dom Duarte terá então prometido as casas a Rui Borges. A promessa vem a ser cumprida por Dom Afonso V na data referida. Pouco depois, em 1440/05/30, Rui Borges cessou funções na alfândega, deixando o cargo de almoxarife a Álvaro Borges, seu irmão (ANTT, Ch. Afonso V, L. 20, fl. 112v).

A doação das casas, que tinha sido feita "deste dia pera todo o sempre", veio a ser reiterada a "Ruy Borjes, caualeiro de nossa casa" em 1449/07/18 (ANT, Leit. Nova, Estrem., L. 8, fl. 266). Esta confirmação ocorreu apenas dois meses após a batalha de Alfarrobeira, indicando que Rui Borges terá estado do lado do rei (Moreno 1979-1980, II: 741-742).

O senhorio de Carvalhais também deve ter sido doado a Rui Borges logo após a batalha de Alfarrobeira, em que morreu o anterior senhor da terra, precisamente o infante Dom Pedro. A doação não aparece, mas terá ocorrido provavelmente em data próxima da confirmação da posse das casas de Lisboa. Certo é que, em 1450/04/20, a pedido de Rui Borges, Dom Afonso V confirmou aos moradores das terras do senhorio de Carvalhais o privilégio de usarem a sua jurisdição. Nessa confirmação, o rei refere que "o dito Ruy Borjes nos pedio por merece que, por quanto the nós hora fezeramos mercee das ditas terras ..." ${ }^{6}$. Esta doação vem reforçar a convicção de que Rui Borges terá estado ao lado do rei no conflito que terminou em Alfarrobeira.

Em 1464/09/26, sendo ainda vivo Rui Borges, é feita a doação do senhorio de Carvalhais, com Ferreiros, Avelãs de Cima, Ílhavo, etc., ao filho Gonçalo Borges, nos seguintes termos:

“... praz-nos que, por falleçimento do dito Rui Bories seu padre, elle [Gonçalo Borges] tenha e aia de nos [as ditas terras] em sua uida [...], que per trespassamemto do ditto Rui Bories, metam loguo o dito Guomçallo Bories em posse das ditas terras [...], porque nossa merçee he loguo d'agora pera emtam fazermos merçee das ditas terras ao dito Guomçallo Bories per a dita guisa" 7 .

A doação abrangia a "iurdiçam çiuell e crime, mero e misto imperio", "padroados de igrejas que nos em elles auemos", rendas, foros, etc. O rei reservava para si a correição e alçada, confirmação dos tabeliães, sisas, dízima nova e serviço novo dos judeus. Esta doação abrangia ainda as já referidas casas de Lisboa:

"Outrossi fazemos merçee ao dito Guomçallo Bories, em sua uida, per falleçimento do dito seu padre, das nossas casas que elle [Rui Borges] ora de nos tem na padaria de Lixboa, assim pella guisa que o dito seu padre de nos ha e possui".

6 ANTT, Gav. 15, m. 11, n.o 47; Reform. Gav., L. 29, fl. 232v-234v. Inclui carta de 1416/04/04 a Martim de Ocem. A transcrição em Leit. Nova, Estrem., L. 8, fl. 265-266, é parcial.

7 ANTT, Ch. Afonso V, L. 14, fl. 108v; Leit. Nova, Estrem., L. 10, fl. 289v-290. 
O rei justifica, em parte, a doação a Gonçalo Borges com os "muitos e continuados serviços que Rui Borgees, do nosso comsselho, tem feitos a el Rey meu senõr e padre" e, portanto, "grandes merecimentos do dito seu padre", que o rei pretendia "galardoar". A carta não identifica os serviços em causa, mas sendo serviços prestados no reinado de Dom Duarte, serão os serviços prestados enquanto almoxarife da alfândega de Lisboa. O apoio a Dom Afonso V no conflito com o infante Dom Pedro também deve ter contado.

Várias outras fontes documentam o Rui Borges, senhor de Carvalhais:

1. Em 1456/03/03, João Alvares foi nomeado escrivão das sisas de Carvalhais, São Lourenço do Bairro, Avelãs do Caminho e Aguada de Baixo, dizendo-se que era morador em "Famalicam [f. Avelãs de Cima], terra de Ruy Borjes, caualeiro da nossa cassa" (ANTT, Ch. Afonso V, L. 15, fl. 9v).

2. Em 1464/09/03, foram doados a "Ruj Borjes, fidalgo da nossa casa" alguns bens em Vagos e Ílhavo que tinham sido confiscados a um morador em Vagos (ANTT, Ch. Afonso V, L. 8, fl. 70v.).

3. Pelo inventário dos pergaminhos do Mosteiro de Jesus de Aveiro, sabe-se também que Rui Borges aforou uma "agoa em Val de Ilhavo" a João de Penela, escrivão do almoxarifado de Aveiro, com obrigação de este construir um moinho ${ }^{8}$.

Rui Borges era membro do Conselho del Rei, como se vê, em 1463, na legitimação do filho, referida adiante ("Rruy Borjes, do consselho") e, no ano seguinte, na doação a esse filho ("Rui Borges, do nosso comsselho"). Morreu, o mais tardar, nos primeiros meses de 1466. De facto, em 1466/07/09, a viúva do referido João de Penela doou ao Mosteiro de Jesus de Aveiro o moinho que este tinha construído no "termo d'Illjauo, terra de Gonçalo Borges".

Rui Borges relacionou-se com uma mulher solteira, Maria Vaz, de quem teve o único filho já referido, no qual continuou o senhorio.

8 MJA, II/3: 723-725. Não foi possível localizar o documento. A data indicada no inventário é "28 de Janeiro de 1439", o que não faz sentido, porque a terra tinha sido dada ao infante Dom Pedro dois anos antes, só tendo sido dada a Rui Borges em 1450 ou pouco antes.

9 A doação do moinho, incluindo casas e levada, foi outorgada por Catarina Gonçalves, viúva de João de Penela, por alma de seu marido e filhos, com a condição de o mosteiro continuar a pagar o foro ao senhorio (Pergaminhos do Mosteiro de Jesus de Aveiro, Gaveta I, Pasta 1, n. ${ }^{\circ} 254$, no Arquivo da Universidade de Coimbra, V-3. ${ }^{\text {a }}$ D-M6-G1-25). O "Ruy Borges cavaleiro", fidalgo da casa real documentado em 1469 (Provas, II, doc. 8: 29), já não pode portanto ser o Rui Borges, senhor de Carvalhais, como admitiu Moreno (1979-1980, II: 742). Seria talvez o homónimo, que sabemos ter sido filho de Gomes Borges, e que também já tinha morrido em 1478 (Rosa 1995: 61). 


\section{Gonçalo Borges de Carvalhais}

Foi cavaleiro fidalgo da casa real e porteiro-mor. Em 1463/10/24, "Gonçallo Borjes, filho de Rruy Borjes, do Conselho, e de Maria Vaaz, molher solteira ao tempo de sua nascença", foi legitimado por Dom Afonso $\mathrm{V}$, a pedido do pai ${ }^{10}$. Com a legitimação, Gonçalo Borges ficava habilitado a "trazer armas dereitas de sua jeeraçom [...] como outro qualquer fidalgo faria ou poderia fazer se de legitimo matrimonio nado fosse".

Foi senhor de Carvalhais, Ferreiros, Avelãs de Cima, Ílhavo, etc., pela doação de 1464/09/26, já referida acima (ver nota 7). Pela mesma doação, foi senhor das casas da Rua da Padaria, em Lisboa, que também vinham de seu pai, facto que o liga de forma categórica ao almoxarife Rui Borges, e não a qualquer homónimo que possa ter existido na mesma época. Seria ainda muito novo nessa altura, porque o rei justifica a doação dizendo que Gonçalo Borges, "segumdo sua hidade, nos tem muy bem servido".

Em 1462, ainda antes da legitimação, "Gonçalo Borges de Carvalhaes" já era moço fidalgo da casa real com uma moradia de 900 reais (Provas, II, doc. 8: 42). Em 1466/07/09, na doação do moinho citada acima, já aparece como senhor de Ílhavo, portanto teria sucedido a seu pai no senhorio de Carvalhais.

Em 1469, o mesmo "Gonçalo Borges de Carvalhaes" já era cavaleiro fidalgo da casa real com uma moradia de 1800 reis (Provas, II, doc. 8: 25). Em 1475, "Gonçalo Borges de Carvalhaes, Porteiro-Mor” continuava a auferir a tença de 1800 réis (id., ibid.: 34). Por esta referência, vê-se que Gonçalo Borges era porteiro-mor, cargo cuja principal responsabilidade seria controlar o acesso ao rei através do controlo das portas do palácio, coordenação dos porteiros, etc. (Sousa 17351749, IV: 744). Mais tarde, em 1499/08/29, Dom Manuel confirmaria a Gonçalo Borges, fidalgo e ainda porteiro-mor, uma tença (anual) de 20000 reais (ANTT, Ch. Manuel I, L. 41, fl. 108v). É de notar que os 1800 réis mensais importavam em 21600 reis anuais, montante que em 1499 terá sido arredondado para 20000 réis. Nessa altura, foi apresentada uma carta datada de 1467/03/06, na qual se terá estipulado pela primeira vez a tença.

Casou em 1468, ou no ano anterior, com Isabel de Sousa. Em 1468/03/28, "dona Isabel de Sousa, filha d'Afomsso de Miramda, do nosso comselho, e mulher de Gomçallo Borges, fidallguo de nossa casa e nosso porteiro-mor" obteve de Dom Afonso V uma tença de 1500 coroas de ouro "pera ajuda de seu casamento" (ver nota 13). Como o próprio Afonso de Miranda ocupava o cargo de porteiro-mor em 1450 e ainda voltou a ocupá-lo em 1469, tudo indica que Gonçalo Borges

10 ANTT, Ch. Afonso V, L. 9, fl. 161v; Leit. Nova, Legit., L. 2, fl. 225; id. Míst., L. 3, fl. 41v; já citado por Moreno, 1979-1980, II: 742. 
sucedeu a seu sogro no cargo $^{11}$. Gonçalo Borges era porteiro-mor em 1468 e novamente em 1475, 1476, 1497 e 1499, mas pelo meio houve outros. Um deles foi o próprio sogro, em 1469. Em 1484, o porteiro-mor era Gomes Ferreira (Provas, II, doc. 29: 177).

Em 1476/07/30, Dom Afonso V prometeu a "Gonçallo Borjes, fidalguo da mjnha casa e porteiro moor" doar a "huum seu filho que delle ficar" as terras que aquele trazia por doação régia ${ }^{12}$. Em 1497/07/18, ainda foi referido como "Gomçallo Borges, fidallguo de nossa casa e nosso porteiro mor" (ver nota 13). Em 1498/02/12, um criado de Gonçalo Borges teve uma mercê régia (ANTT, Ch. Manuel I, L. 28, fl. 86v). Em 1504/04/15, Isabel de Sousa ainda foi referida como "mulher de Gomçallo Borges" (ver nota 13), indicando que este ainda estaria vivo. Terá morrido talvez por volta de 1510, com cerca de 60 anos. Em 1512, a tença referida parece que tinha passado para o filho e em 1513 este já aparece como senhor de Carvalhais.

Sendo referido nas listas de moradores da Casa Real como "Gonçalo Borges de Carvalhais", fica-se com a impressão de que Carvalhais seria a sua residência principal quando não estava na corte. No entanto, consta também que lhe "chamarão da Arruda, parece que por viver nesta villa" (Alão <1693, V, 1:25-26). Houve de facto uma ligação dos Borges à região de Torres Vedras, Monte Agraço e Arruda, a partir do reinado de Dom João I (ver adiante secção V.1). Essa ligação poderá ter sido determinante para o casamento de Gonçalo Borges. $\mathrm{Na}$ verdade, o sogro foi precisamente comendador de Torres Vedras na Ordem de Cristo e alcaide-mor da mesma vila. A ligação parece que se prolongou para além da morte de Gonçalo Borges uma vez que, num fragmento de pergaminho do cartório notarial de Torres Vedras, ainda surge "Dona Isabel, viuva do porteiro moor" aforando um chão em nome de suas filhas órfãs (Pinto 2014: 48).

Na igreja paroquial da Moita (c. Anadia), mais precisamente na capela de São Gregório, que foi a capela dos Borges, conserva-se um túmulo que Gonçalves (1959: 81) datou de finais do século XV (Fig. 2). O túmulo ostenta um escudo pleno com leão rompante que aquele autor interpretou como representando as armas dos Borges, caso em que poderia ser o túmulo de Gonçalo Borges. No entanto, falta-lhe a bordadura de flores-de-lis característica das armas dos Borges (Freire 1921-1930, I: 89). Sem essa bordadura, as armas representadas são as

11 ANTT, Ch. Afonso V, L. 34, fl. 30, de 1450/03/21, e numa lista de moradores da casa de Afonso V relativa ao ano de 1469 (Provas, II, doc. 9: 23). Em 1474, voltamos a encontrar referência a Afonso de Miranda entre os cavaleiros do conselho, já sem indicação de ser porteiro-mor (Provas, II, doc. 9: 24). Os livros de linhagens do século XVI também referem Afonso de Miranda como porteiro-mor (Góis 1560: 103-104; LLS16: 327; LLRP, fl. 47v). A família de Violante de Sousa, sogra de Gonçalo Borges, está igualmente bem documentada (Góis 1560: 341; LLS16: 129-130; Freire 1921-1930, II: 128 e 131; Vasconcelos 2012: 554-585).

12 ANTT, Leit. Nova, Estrem., L. 7, fl. 142v. 
dos Silvas, família do avô materno de Isabel de Sousa. Talvez, pois, este túmulo tenha sido de Isabel de Sousa e não de seu marido. O apelido Silva ainda seria recuperado por uma filha, Joana, e por dois netos do casal.

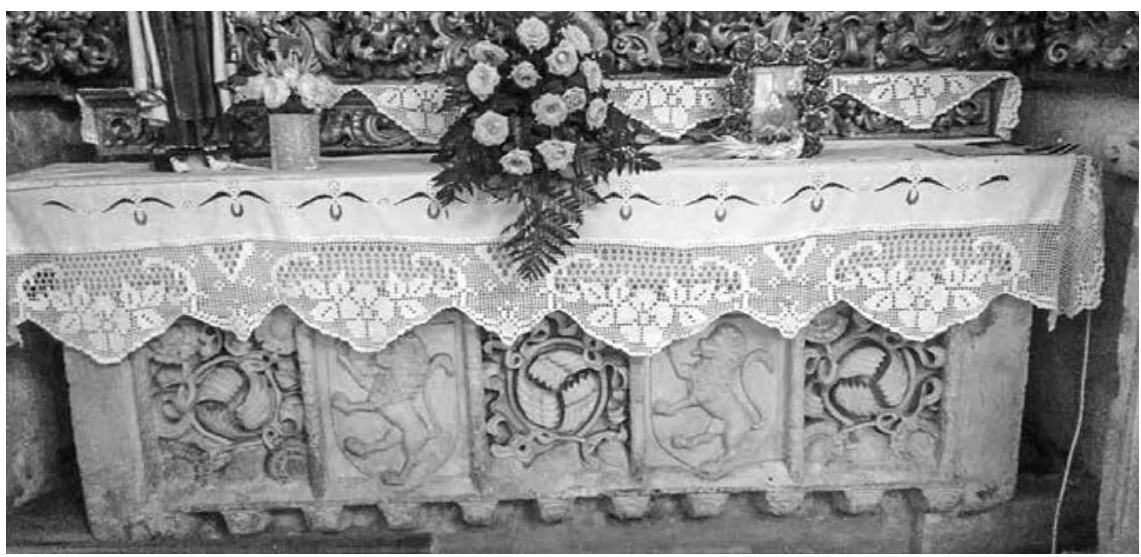

Fig. 2. Arca tumular do início do século XVI, com armas dos Silvas, existente na antiga capela dos Borges, que ainda hoje se conserva na igreja de Santiago da Moita (c. Anadia)

Filhos:

- António Borges de Miranda, que segue.

- Filipa de Sousa, c.c. Rui Pereira. Em 1504/04/15, Dom Manuel I transferiu a tença de Isabel de Sousa, a pedido desta, para seu genro Rui Pereira, fidalgo da casa real ${ }^{13}$. Em 1506/03/06, antes de partir para a Índia, Rui Pereira vendeu a tença a Fernando Coutinho (ANTT, Ch. Manuel I, L. 15, fl. 35v, de 1513/09/27). Trata-se seguramente de Rui Pereira Coutinho, capitão de uma das naus da armada de Tristão da Cunha, que partiu de Lisboa em 1506/04/06 (Góis 1558: 376378). Rui Pereira morreu nessa viagem na sequência de uma tempestade ao largo de Madagáscar.

- "Ruy Borges, irmaõ de Antonio Borges”, cavaleiro da casa de Dom João III, com uma moradia de 2000 reis (Provas, II, doc. 132: 799). Terá casado pelo menos uma vez, sem geração (Alão <1693, III, 1: 177; Gayo <1831, VII, tit. “Borges”, $\$ 31$, n. $\left.{ }^{9} 9\right)$.

- Joana da Silva, c.c. Gonçalo da Silva, senhor de Abiul (LLS16: 127; Alão <1693, II, 2: 203). Em 1521/08/06, Dom Manuel I concedeu uma tença anual de 18000 réis a Joana da Silva, então já viúva de Gonçalo da Silva (ANTT, Ch. Manuel I, L. 18, 3v).

13 ANTT, Ch. Manuel I, L. 15, fl. 35v36, e L. 19, fl. 11; Leit. Nova, Míst., L. 2, fl. 277v-278. Inclui a carta de Dom Afonso V, datada de 1468/03/28, que concedia a tença a Isabel de Sousa, bem como a respectiva confirmação, por Dom Manuel, em 1497/07/18. 


\section{António Borges de Miranda}

Frequentemente referido como António Borges, era cavaleiro do Conselho del Rei Dom Manuel I (Provas, II, doc. 65: 353-356). Recebia 20000 reis de tença anual, facto documentado entre 1512 e $1528{ }^{14}$. Parece ser a tença anteriormente atribuída a seu pai.

Como referido, a doação de Carvalhais foi confirmada a um filho de Gonçalo Borges em 1476. António Borges seria muito jovem ainda nessa altura. O foral manuelino de ílhavo, dado em 1514/03/08, já o refere no capítulo dos montados: "E assy aproune a Amtonyo Borges que ora tem de nos os ditos direitos reaaes" (Madahil 1922, doc. 11: 61; 1939: 187). No ano anterior, António Borges de Miranda tinha aforado um mato maninho a Duarte Borges, prior da Igreja de Ílhavo, possivelmente seu parente ${ }^{15}$.

No cadastro de população de 1527, António Borges aparece como senhor nos três concelhos em que se dividia o senhorio (Freire 1908: 277; Colaço 1929: 156 e 159). Nesse espaço viviam então cerca de 1300 pessoas em 327 fogos e dezenas de povoações, hoje dispersas pelos concelhos de Anadia, Ílhavo e Aveiro. Em 1528/08/03, ainda foi emitida provisão para ser paga a tença anual a António Borges de Miranda (ver nota 14) e em 1529/01/23 ainda lhe foi passada carta para apresentar o meirinho de Carvalhais (ANTT, Ch. João III, L. 50, fl. 12v). Morreu ainda em 1529, ano em que Dom João III confirmou a posse do senhorio ao filho.

Segundo os nobiliários do século XVI, António Borges de Miranda terá casado em primeiras núpcias com Margarida Henriques, filha de Afonso Henriques, senhor de Barbacena e alcaide-mor de Portalegre, e de sua mulher Lucrécia Pereira de Berredo ${ }^{16}$. Entretanto, em 1525/04/13, António Borges estava consertado para celebrar segundo casamento, com Antónia Pereira de Berredo, prima co-irmã da sua primeira mulher (Alão <1693, I, 2: 127-128), aguardando para isso licença papal. Nessa data, Dom João III doou as "terras de Carvalhaes e Ilhavo", por morte de António Borges, ao filho varão primogénito que ficasse do casamento com Antónia Pereira. A doação passaria depois para a descendência varonil desse filho até um bisneto de António Borges (Madahil 1922, doc. 12: 68). Deste segundo casamento nasceu efectivamente um filho, Rui Pereira de Miranda, que sucedeu no senhorio de Carvalhais.

14 ANTT, Corpo Cron., Parte II, mç. 33, n.o 19 (1512); idem, mç. 64, n.o 62 (1516); idem, mç. 69, n.o 191 (1517); idem, mç. 109, n.o 144 (1523); idem, mç. 135, n.o 90 (1526); idem, mç. 141, n.o 105 (1527); idem, mç. 150, n.o 81 (1528).

15 Museu Nac. Arq., Pergam. Diversos, 16737, Ms/P/DIV, cx. 9, n.o 308.

16 Góis 1560: 115; LLS16: 245-246; LLRP, fl. 53v; Alão <1693, I, 2: 127; Freire 1921-1930, III: 153-158; Vasconcelos 2012: 450-453 e 678. Não há coincidência total nas informações. 
Numa lista de moradores da casa de Dom João III, são identificados quatro outros filhos (Provas, II, doc. 132). Esta lista não refere Rui Pereira de Miranda, talvez por ser ainda muito novo. Supõe-se, assim, que os filhos que aparecem na lista sejam do primeiro casamento. Entretanto, se uns, presumindo que António Borges seria de idade avançada, duvidaram que pudesse ser pai de Rui Pereira, outros caíram no extremo oposto, atribuindo ao segundo casamento nada menos do que cinco filhos (Gayo <1831, VII, tit. "Borges", \$30, n.o 10: 105). Ora, tal também não é plausível porque António Borges morreu apenas quatro anos após o casamento. Em todo o caso, na confirmação da doação a Rui Pereira, refere-se que este "era o filho mais velho que por falecimento do dito António Borges, seu pae, ficára”, sugerindo que poderá ter havido mais filhos do segundo casamento. Um deles parece de facto ter sido filho do segundo casamento. Os filhos que foi possível identificar são os seguintes:

- "Antonio Borges, filho de Antonio Borges", que aparece como cavaleiro na lista de moradores da casa de Dom João III (Provas, II, doc. 132: 803). Deverá identificar-se com o António Borges que teve carta de cavaleiro em 1522/06/05 (ANTT, Ch. João III, L. 1, fl. 51). O “António de Miranda, filho de António Borges de Miranda”, que foi para a Índia em 1560 (Emmenta, 26: 29), poderá ser ainda o mesmo, ou já um neto.

- "Heytor Borges, filho de Antonio Borges de Miranda", que aparece como escudeiro fidalgo na lista de moradores da casa de Dom João III (Provas, ib.: 825). Em 1560, "António de Miranda, filho de Heytor Borges e de D. Joanna de Maris, moradores em Aveyro", foi para a Índia (Emmenta, 26: 29).

- [?] “Dona Guiomar da Silva”, falecida na freguesia da Moita em 1571/10/20, com testamento.

- [?] Luísa Henriques, freira em Lorvão, que em 1582 deixou aos priores da Moita algumas propriedades para se rezarem 12 missas por ano na capela de São Gregório, por sua alma e de seus pais, e para a sustentação da capela (Silveira 1910-1911). Uma lápide existente na igreja da Moita informa que a capela de São Gregório "tem $p$ [er] a esmola e cera das missas e se ace[n] der a ala $[\mathrm{m}] p[\mathrm{a}] d a$ [nos] $d[$ oming] os e dias $s[\mathrm{na}]$ tos $h v[\mathrm{~m}]$ as ieiras e $[\mathrm{m}]$ Pereira $q[\mathrm{ve}] p[\mathrm{ar}] a$ isto foraõ $e[\mathrm{n}]$ tregves aos priores desta igr $[\mathrm{ej}] a$ " (Gonçalves 1959: 82). Atendendo ao apelido, deverá ter sido filha de António Borges de Miranda e de sua primeira mulher.

- "Simaõ de Miranda, filho de Antonio Borges", que também aparece como escudeiro fidalgo da casa de Dom João III (Provas, ib.: 826). Deve identificar-se com o "Simão de Miranda" matriculado em Leis na Universidade de Coimbra em 1538/11/28 (AUC, IV-1ªD-1-1-3, fl. 176v) e com o "Simão de Miranda Anriques" que obteve o grau de bacharel em Leis dois anos 
depois, em 1540/10/23 (id., cad. 3, fl. 46v). Deve ainda identificar-se com o "Simão de Miranda Henriquez, comendador de Malta", assim nomeado num letreiro da capela de Nossa Senhora do Socorro, por si fundada em Avelãs de Cima em 1592 (Henriques 1721).

- "Gonçalo da Silva, filho de Antonio Borges de Miranda", que aparece como moço fidalgo na lista de moradores da casa de Dom João III (Provas, ib.: 839). Terá sido clérigo (Alão <1693, III, 1: 177; Gayo <1831, VII, \$30, n. ${ }^{9}$ ). Deverá identificar-se com o Gonçalo Borges, moço fidalgo da casa real e filho de António Borges, que em 1533 recebia uma tença de 20000 réis paga no almoxarifado de Aveiro ${ }^{17}$.

- Rui Borges Pereira, ou Rui Pereira de Miranda, do segundo casamento, que segue.

- "Francisco Borges de Miranda, filho de António Borges de Miranda", que foi para a Índia em 1560 (Emmenta, 26: 29). Uma vez que, tal como Rui Pereira de Miranda, não consta da lista de moradores da casa de Dom João III (Provas, II, doc. 132), deverá ser um filho mais tardio, provavelmente também do segundo casamento de seu pai.

\section{Rui Pereira de Miranda}

Nascido provavelmente em 1526, já estava órfão de pai em 1529/11/16, data em que Dom João III confirmou "Ruy Borges Pereira" como senhor de Carvalhais (ANTT, Ch. João III, L. 48, fl. 124-124v; Madahil, 1922, doc. 12: 67-69).

Rui Pereira de Miranda terá casado em 1543 com Catarina de Ataíde, filha de Álvaro de Sousa, senhor de Eixo, Requeixo e Óis da Ribeira ${ }^{18}$. Esta primeira mulher faleceu em 1551 (Gonçalves 1959: 108) sem geração. Rui Pereira de Miranda casou depois com Ana da Cunha, filha de João de Castilho, escrivão da câmara de Dom João III, escrivão da fazenda de Dom Sebastião, do Conselho del Rei Dom Henrique e alcaide-mor de Alenquer ${ }^{19}$. Em 1570, o casal terá instituído um morgado, com sede na capela de São Gregório Magno, que ainda se conserva na igreja da Moita (Silveira 1910-1911). Uma lápide existente nesta igreja informa que "A capella de Sam Greg[o]rio te[m] obrigacaõ de dvas missas cada somana pela alma de sevs fvndadores" (Gonçalves 1959: 82). A partir daqui, os senhores de Carvalhais passaram a ser também conhecidos como "morgados de Carvalhais".

\footnotetext{
ANTT, Corpo Cron., Parte II, mç. 182, n. ${ }^{\circ} 138$.

18 Alão, <1693, III, 1: 178; Silva, <1705, II: 286; Sousa, 1735-1749, XII: 568-571; Silveira, 1910-1911; Vasconcelos, 2012: 572 .

19 LLRP, fl. 278-278v.
} 
Em 1574/12/16, Dom Sebastião ainda confirmou a posse do senhorio de Carvalhais a "Ruy Pereira de Miranda, fidalgo da minha casa, que se chamava Ruy Borges Pereira" (Madahil 1922, doc. 12: 6769). Morreu pouco tempo depois, com perto de 50 anos, deixando filhos do segundo casamento:

- André Pereira de Miranda, que segue.

- "Francisco Pereira de Miranda", que levantou em 1616/05/27 uma grande cruz de pedra no Monte Crasto, Anadia, com um letreiro que o identificava como filho de "Ruy Pereira de Miranda e D. Anna da Cunha" (Henriques 1721). Em 1595, "Francisco Pereira de Miranda, filho de Ruy Pereira" era um dos "fidalgos cavalleiros" da casa real com moradia de 2000 reais por mês e um alqueire de cevada por dia (Provas VI: 646). Por morte de Simão de Miranda Henriques, foi o $2^{\circ}$ administrador da capela de Nossa Senhora do Socorro. Terá casado duas vezes, sem geração. Transmitiu a sua Quinta da Graciosa e a administração da capela a Sebastião Pereira de Miranda, filho do irmão que se segue (Guerra 1965: 331-332).

- "Luis Pereira de Miranda, filho de Ruy Pereira e Dona Anna", que casou em Avelãs de Cima em 1581 com Maria de Mariz, da Figueira de Boialvo, filha de Heitor de Mariz e Helena de Figueiredo. Enviuvando, Luís Pereira de Miranda fez-se clérigo. Em 1609, foi bispo de Cabo Verde, morrendo ao fim de um mês (Sousa 1722). São o tronco da família da Quinta da Graciosa (Guerra 1965).

- [?] "Dona Vilante de Miranda, moradora em Saõ Pedro [de Avelãs de Cima]”, que morreu em 1607/02/25. Fez testamento em que deixou os bens a um António Francisco e sua mulher. Os registos paroquiais referem-se-lhe sempre como "Dona" ou "Senhora Dona" e vê-se que tinha uma relação próxima com os principais membros da família dos senhores de Carvalhais.

\section{André Pereira de Miranda}

Sendo o primogénito do segundo casamento de seu pai, deve ter nascido por volta de 1555. Em 1575/07/12, Dom Sebastião confirmou o senhorio de Carvalhais a André Pereira de Miranda, uma vez que o pai tinha morrido (Madahil 1922, doc. 12: 6770). Foi assim $5^{\circ}$ senhor e $2^{\circ}$ morgado de Carvalhais. Em 1575/07/23, obteve mercê régia para que "os tabaleais das suas terras $[\ldots]$ se chamem e se possam chamar por elle Andre Pereira" (id., ib.: 70).

Em 1576, "André Pereira de Miranda, filho de Rui Pereira de Miranda" era moço fidalgo da casa real com 1000 réis de moradia por mês e um alqueire de cevada por dia (Provas, VI: 640). Viveu na freguesia de Santiago da Moita, certamente em Carvalhais, com sua mulher, Filipa de Melo, filha de Rui de Melo 
Pereira, comendador de Ribas na Ordem de Cristo ${ }^{20}$. Documenta-se a participação do "Senhor André Pereira" e da "Senhora Dona Filipa" como padrinhos em vários baptismos realizados na igreja da Moita até finais do século XVI.

Em 1594/09/10, Dom Filipe I confirmou a André Pereira as duas cartas de Dom Sebastião referidas acima (Madahil, ib.: 67-70). Em 1599/12/12, “D. Luísa, sua filha e herdeira, por não haver filhos barões" estava consertada para casar com "Christóvão d'Almada, outrossy fidalgo da minha casa, filho de Fernão Roiz d'Almada". Nessa data, atendendo aos serviços prestados pelos pais dos noivos, Dom Filipe II confirmava a doação do senhorio a essa filha e a seu futuro marido após o falecimento do pai dela, desde que o casamento se concretizasse.

Foi possível identificar as filhas seguintes:

- Luísa de Melo. Em 1601/09/25, tendo morrido André Pereira, Dom Filipe II confirmou o senhorio de Carvalhais a Cristóvão de Almada e a "D. Luisa de Mello, sua mulher" (Madahil, ib.: 67-72).

- Maria, b. 1578/11/04, em Santiago da Moita.

- Ângela de Melo, b. 1579/12/10, em Santiago da Moita, c.c. Francisco de Almeida (Alão <1693, III, 1: 178; Gayo <1831, VII, \$30, n. ${ }^{\circ} 11$ ).

Com André Pereira termina, pois, a linhagem Borges no senhorio de Carvalhais. No entanto, o senhorio manteve-se na descendência dos Borges até ao fim do antigo regime. Essas origens foram lembradas quando o último senhor, D. José Maria de Almada Castro Noronha da Silveira Lobo, foi agraciado com o título de conde de Carvalhais.

\section{Percurso social}

Estando agora esclarecida a série dos senhores de Carvalhais na linhagem dos Borges, será oportuno analisar também o seu percurso social, enquadrando-o no contexto da época.

\section{Origens e ascensão}

Se as razões que justificaram a doação do senhorio de Carvalhais a Rui Borges ficaram razoavelmente clarificadas na secção IV.1, será relevante perceber melhor os antecedentes da ascensão deste ramo dos Borges na sociedade da época.

20 Gayo < 1831, VII, tit. “Borges”, \$30, n.o 10. 
A mudança dinástica com que culminou a crise de 1383-1385 deu oportunidade a uma renovação da nobreza, recompensando os indivíduos que tomaram o partido do mestre de Avis e penalizando os que tomaram o partido castelhano. O desempenho de funções militares, nomeadamente em África, continuou naturalmente a oferecer oportunidades de ascensão na sociedade da época (Cunha, Monteiro 2010).

Entretanto, a tendência para a curialização da nobreza, ditada pela crescente centralidade da corte na sociedade portuguesa, acentuou-se ao longo do século XV (Gomes 1995). Ao mesmo tempo, a burocracia régia, agora essencialmente laica e profissionalizada, constituiu-se num veículo importante para a ascensão social, dando origem à chamada nobreza de serviço. São relativamente abundantes os casos de famílias que, partindo das camadas populares ou da baixa nobreza, ascenderam na sociedade do século XV essencialmente pela via do desempenho de cargos na administração central. O caso dos Silveiras de Alvito, foi detalhadamente estudado por Caetano (2011). O mesmo autor recapitula alguns casos comparáveis: Castelobrancos, Silveiras de Sortelha, Alvarengas, Galvões e Lucenas.

Como se enquadram os Borges de Carvalhais neste contexto? A tentativa de resposta a esta pergunta encontra algumas dificuldades. De facto, os nobiliários mais antigos são praticamente omissos quanto aos Borges e a restante documentação não permitiu até agora esclarecer de forma fiável e inequívoca a ligação de Rui Borges, $1^{\circ}$ senhor de Carvalhais, a outros indivíduos que usaram o mesmo apelido nos séculos XIV e XV. Ainda assim, algumas hipóteses plausíveis podem ser colocadas.

Os Borges começam a ter alguma visibilidade na sociedade portuguesa a partir de meados do século XIV. O epicentro parece estar a norte. Em 1363, contavam-se entre os naturais do mosteiro de Pedroso três indivíduos com o apelido Borges, com alguns filhos e filhas (São Payo 1987: 63). Um deles, Gonçalo Anes Borges, que tinha nessa altura dois filhos, também aparece como natural do mosteiro de Grijó em 1365 (Pizarro 1987: 451).

Nas décadas seguintes, encontramos vários indivíduos com os apelidos "Gonçalves Borges" que poderão ser filhos de Gonçalo Anes Borges:

- Gonçalo Gonçalves Borges, muito documentado entre 1374 e 1394, alvazil do crime em Lisboa em 1378-1379, partidário do mestre de Avis na crise de 1383-1385, referido como vassalo do rei em 1385 e beneficiário de um conjunto importante de doações régias antes e depois da crise (Farelo 2008: 449-451).

- Álvaro Gonçalves Borges, comendador do Casal na Ordem de Avis (ANTT, Ch. Fernando, L. 1, fl. 178, 1375/10/05). 
- Gil Gonçalves Borges, a quem Dom João I doou a colheita de São Romão da Beira (CPDJI, I, 3, doc. 1109, 1385/11/25). Deve identificar-se com o Gil Borges, senhor de Alva, Reriz e do jantar de Santa Eulália de Rio de Asnes, terras que depois passaram para Diogo Borges, comendador do Torrão, provavelmente seu filho (CPDJI, III, 2, doc. 575, 1433/03/09).

- Diogo Gonçalves Borges, a quem Dom João I doou Ourilhe, Calvos e a portagem de Arco de Baúlhe (CPDJI, I, 2, doc. 773, 1385/06/14).

Este último, legitimado em 1374/03/23, é o único que se sabe ter sido filho de Gonçalo Anes Borges (ANTT, Ch. Fernando, L. 1, fl. 142v). Os outros talvez fossem seus filhos legítimos. Os dois últimos beneficiaram de doações régias em 1385, indicando que, tal como Gonçalo Gonçalves, terão estado ao lado do mestre de Avis na crise dinástica.

Dos Borges até agora referidos, Gonçalo Gonçalves Borges, parece ter sido o primeiro a fixar-se na região de Lisboa. Além do importante património já conhecido - em Celorico de Basto, Leiria, Monte Agraço e Oeiras (Farelo 2008: 449-451) -, Gonçalo Gonçalves teve também propriedades em Torres Vedras e Arruda. Com efeito, em 1423/03/24, o infante Dom João, mestre da Ordem de Santiago, emprazou a "quintãa da Revaldeira" em três vidas a "Alvaro Borges, escudeiro". Esta propriedade estava localizada "em termo de Torres Vedras, como parte com quintãa que foy de Gonçalo Gonçalves Borgez". O emprazamento abrangia ainda um casal "no termo da Aruda, que chamom Moynho do Vento, que parte com casal de Gonçallo Gonçalvez Borges, ho qual casal sempre andou com a dicta quintãa da Revaldeira" (Livro dos Copos, I, doc. 205). Deve ser o mesmo Álvaro Borges que, em 1428/10/15, é referido como tesoureiro do mestre de Santiago (Livro dos Copos, I, doc. 135). Deve ainda identificar-se com o "Alvaro Borges almoxarife d'el Rey na alfandega de Lixboa", que em 1440/08/17 foi testemunha num aforamento outorgado pelo mesmo infante Dom João (Livro dos Copos, I, doc. 174). Este seria portanto o Álvaro Borges, irmão de Rui Borges, que sabemos ter-lhe sucedido como almoxarife da alfândega de Lisboa (ver secção IV.1). As relações de vizinhança em Torres Vedras e na Arruda sugerem a existência de uma relação familiar próxima entre Álvaro (e Rui) Borges e o falecido Gonçalo Gonçalves. Como se viu na secção IV.2, a ligação a esta região ainda se mantinha na geração do $2^{\circ}$ senhor de Carvalhais.

Segundo alguns nobiliários, Rui Borges seria na verdade filho de Diogo Gonçalves Borges, senhor de Ourilhe, etc. (Tabela I). Esta hipótese surge sem qualquer fundamentação nos nobiliários mais conhecidos, mas encontra-se fundamentada no nobiliário de Diogo Gomes de Figueiredo, obra do século XVII injustamente esquecida (Tarouca 1946). Reportando-se a documentação do início do século XVI, o autor afirma que Rui Borges, $1^{\circ}$ senhor de Carvalhais, 
era irmão de Gomes Borges, escrivão da chancelaria régia, de Gonçalo Borges, abade comendatário de Refoios de Basto, e de Duarte Borges, camareiro-mor de Dom Duarte, todos filhos de Diogo Gonçalves ${ }^{21}$. De acordo com os restantes dados, seriam provavelmente sobrinhos de Gonçalo Gonçalves.

Seja como for, parece lícito resumir que os Borges em que entroncam os senhores de Carvalhais se enquadram nas tendências gerais da nobreza em ascensão ao longo da dinastia de Avis. Partindo de uma origem na média nobreza regional, alguns elementos da família aproximam-se da corte, tomam o partido do mestre de Avis na crise dinástica e são recompensados por este. Ao longo do século $\mathrm{XV}$, vários elementos da família ocupam lugares com algum destaque na corte (conselheiro régio, camareiro-mor, porteiro-mor, escrivão da chancelaria, almoxarife da alfândega de Lisboa, etc.) sendo recompensados por esses serviços.

\section{As alianças matrimoniais}

Se a proximidade ao monarca e o desempenho de ofícios na corte facilitavam a sempre almejada ascensão na escala social, uma estratégia complementar passava pelas alianças matrimoniais, sobretudo com elementos provenientes de linhagens de maior importância (Cunha 2009; Caetano 2011: 31). No caso dos Borges de Carvalhais, a investigação pormenorizada das alianças que estabeleceram, feita nos documentos da época, não caberia no presente artigo. Em todo o caso, a literatura disponível, desde os antigos nobiliários até aos trabalhos académicos mais recentes, fornece informação suficiente sobre o estatuto social da maior parte das famílias a que os senhores de Carvalhais se foram ligando pelo casamento. É de referir em especial o trabalho de Vasconcelos (2012) que, tendo por base reconstituições genealógicas detalhadas, estuda as relações entre a nobreza e as ordens militares nos séculos XIV a XVI. Na secção anterior, ficaram já citadas as principais referências sobre as origens familiares das esposas dos sucessivos senhores de Carvalhais. Essa informação permite caracterizar, em linhas gerais, a forma como foram consolidando a sua posição na sociedade portuguesa da época.

21 "Ruy Borges, senhor de Carvalhais [e] também porteiro-mor del Rey D. Afonso 5o, [con]forme consta, por hum instrumento de testemunhas, tirado no Couto de [Ref] oyos [de Basto] no anno de 1506, em que jura tes[tem] unha de 80 annos de idade, e hum [neto?] de D. Gonçalo Borges $\$$ [10], n.o 3, era [filho] de Diogo Gonçalves Borges, $\[9], n .0^{\circ}$, [ir] mão de Gomez Borges, do dito abbade [D. G] onçalo Borges e de Maria Borges, mulher de [A] lvaro Nunez de Meyrelles, e dos [ma] is que ahi declaramos, e que foy [tam] bem seu irmã õ Duarte Borges [que a] qui dizíamos, sem termos visto [este] instrumento, poderia ser seu pay [...]. [O in] strumento que dizemos

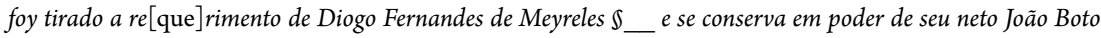
Pimentel, que no lo co[mu]nicou." (Figueiredo <1682, VII, tit. "Borges": 365, nota à margem, ligeiramente mutilada, em que o autor corrige o que ele próprio tinha escrito no seu texto inicial sobre esta família). 
$\mathrm{O} 1^{\circ}$ senhor de Carvalhais, Rui Borges, teve o seu único filho de uma mulher solteira, não se sabendo se chegou a casar. Apesar da obscuridade das origens, o $2^{\circ}$ senhor, Gonçalo Borges, ligou-se pelo casamento a famílias da média e alta nobreza - Mirandas, Silvas, Sousas - com vários parentes próximos na posse de senhorios jurisdicionais e/ou tendo desempenhado cargos importantes, como porteiro-mor, chanceler-mor e alferes-mor. Pelos Sousas, entroncavam em Dom Afonso III. Por sua vez, o $3^{\circ}$ senhor de Carvalhais, António Borges, casou em primeiras núpcias com uma bisneta de Henrique II de Castela. $\mathrm{O} 4^{\circ}$ senhor, Rui Pereira de Miranda, parece ter casado também em primeiras núpcias nos Sousas, num ramo que possuía vários senhorios jurisdicionais e que tinha desempenhado cargos próximos do rei (mordomo-mor, pajem de lança). São de realçar também as ligações às ordens militares, sobretudo às de Cristo e de Santiago. Estas ligações estão presentes em quase todas as famílias a que os senhores de Carvalhais se ligaram pelo casamento.

Quando a varonia Borges se extinguiu, a herdeira, Luísa de Melo, 6. a senhora de Carvalhais, casou com Cristóvão de Almada, sobrinho materno do famoso marquês de Castelo Rodrigo, Cristóvão de Moura, Vice-Rei de Portugal (Gayo $<1831$, II, tit. "Almada", \$8, n. ${ }^{\circ} 10-11$ ). Este, nascido numa família da fidalguia empobrecida, tinha conseguido guindar toda a sua rede familiar ao topo da pirâmide nobiliárquica, graças ao papel político desempenhado junto de Filipe II (Cunha, Monteiro 2010).

Em resumo, poderá dizer-se que as opções matrimoniais dos senhores de Carvalhais oscilaram entre a média nobreza ligada à corte e a alta nobreza, contribuindo certamente para consolidar a sua posição e assegurar a renovação do senhorio de Carvalhais ao longo das sucessivas gerações da linhagem.

\section{O primogénito e os seus irmãos}

Com a primazia dada ao varão primogénito a partir do século $\mathrm{XV}$, as linhagens organizam-se e hierarquizam-se de forma a facilitar, quer a sua ascensão na pirâmide nobiliárquica, quer a sua perpetuação no tempo (Cunha, Monteiro 2010; Sousa 2013). Surgem assim as casas nobiliárquicas, construção social cuja reprodução era um objectivo que tendia a sobrepor-se aos destinos individuais dos seus membros. Cunha (2009), com base numa análise exaustiva de dois grupos familiares, os Cunhas e os Meneses, desde o século XV até 1640, estudou as condições que facilitavam a continuidade das casas. $O$ primogénito tendia a resguardar-se da actividade militar de forma a não colocar em risco a perpetuação da casa. A contenção matrimonial era utilizada como estratégia para evitar a dispersão dos bens não sujeitos à regra da primogenitura, embora pudesse colocar em risco a perpetuação da linhagem em caso de extinção do ramo primogénito. 
No caso dos Borges, senhores de Carvalhais, a análise fica limitada pela escassez de informação fiável sobre os irmãos dos sucessivos senhores. Na secção IV foram identificados, com diferentes graus de certeza, 21 filhos dos primeiros 5 senhores de Carvalhais. O baixo número médio de filhos poderá ser mero reflexo da falta de informação.

Descontando os filhos que foram também senhores de Carvalhais, ficamos com 16 indivíduos, dos quais 8 eram homens. Verifica-se que 7 indivíduos terão casado pelo menos uma vez (44\%), 2 tornaram-se religiosos (12.5\% - Gonçalo da Silva e Luísa Henriques) e outros dois não parecem ter casado (12.5\% - Guiomar da Silva e Violante de Miranda). Dos restantes quatro, um não teve geração (Simão de Miranda Henriques), deixando uma capela a um sobrinho, e outro partiu para a Índia em 1560 (Francisco Borges de Miranda). Dois outros elementos da família (um neto e outro que poderá ser filho ou neto do $3^{\circ}$ senhor) partiram também para a Índia no mesmo ano.

Os três primeiros senhores de Carvalhais (Rui Borges, Gonçalo Borges e António Borges de Miranda) mantiveram ligações estreitas à corte e ao Rei. O $4^{\circ}$ senhor, Rui Pereira de Miranda, não parece ter tido papel relevante na sociedade da época, e o $5^{\circ}$ senhor, André Pereira de Miranda, viveu retirado da corte, precisamente em Carvalhais.

A regra habitual da primogenitura teve uma excepção no caso dos senhores de Carvalhais, na transição do $3^{\circ}$ para o $4^{\circ}$ senhor, dando origem a muita especulação. Nas palavras de um genealogista de finais do século XVII, "Ruy Pereira de Miranda succedeo na casa de seu pai por assim o querer D. João III" (Silva <1705, II: 286). Vale a pena rever o caso. Como se viu na secção IV.3, o rei renovou a doação do senhorio de Carvalhais no filho varão primogénito que ficasse do segundo casamento de António Borges de Miranda. Havia no entanto filhos do primeiro casamento que foram preteridos. O rei falava de razões ocultas: a doação era feita, tendo em conta, não só os serviços prestados por António Borges, mas também "por outros respeitos que me movem".

Especulou-se muito sobre as razões que teriam levado Dom João III a não seguir a regra habitual. A segunda mulher, Antónia Pereira de Berredo, "dama da Rainha e também d'el Rey D. João o 30", terá sido amante do rei e terá tido um filho dessa relação, morto prematuramente (Alão <1693, I, 2: 127-128). Com base nos factos, vários autores foram criando um verdadeiro enredo cheio de outros pormenores que não parecem comprovar-se documentalmente. Desde logo, presumia-se que António Borges teria casado de idade avançada com Antónia Pereira e especulava-se que Rui Pereira seria na verdade filho do rei (Gayo <1831, I, tit. “Andrades Freires”, \$52, n. ${ }^{\circ} 7$ ). Nas palavras de Joaquim da Silveira: "Não nos atrevemos a dizer que de sangue do marido gerecesse; os homens de 70 anos são pouco prolíferos". Contudo, António Borges teria cerca de 55 anos à data do segundo casamento, e não os 70 que lhe atribuíram. 
Assim, embora as razões ocultas do rei possam de facto relacionar-se com a sua antiga amante, não parece necessário concluir que Rui Pereira tenha sido gerado pelo próprio rei.

Partindo do pressuposto, errado, de que o "filho do segundo matrimónio estava legalmente fora da sucessão dos vínculos de seu pae", acusava-se o rei de actuar de forma despótica, não respeitando as leis em vigor. A verdade é que a doação a António Borges era vitalícia e por sua morte ficava para Dom Jorge, duque de Coimbra e mestre de Santiago e de Avis. Assim o estabelecia o testamento de Dom João II, como vimos. O rei tinha por isso toda a legitimidade para doar o senhorio a quem entendesse, desde que para tal tivesse a concordância de Dom Jorge. Ora, de facto, por carta de 1525/02/06, o "mestre e duque" viabilizou a continuidade dos Borges em Carvalhais até ao bisneto de António Borges (Madahil 1922, doc. 12: 68).

\section{Conclusão}

Num contexto de história local, verificou-se a inexistência de estudos detalhados sobre as origens e primeiros titulares do senhorio de Carvalhais. Este estudo vem preencher essa lacuna. O senhorio formou-se no início do reinado de Dom João I por agregação dos concelhos de Ferreiros, Avelãs de Cima e Ílhavo, no moderno distrito de Aveiro, em doação régia dessas terras a Gil de Ocem. Com a extinção da linhagem Ocem, estas terras foram integradas no vasto senhorio do infante Dom Pedro. Morto este na batalha de Alfarrobeira, o senhorio de Carvalhais voltou a individualizar-se ao ser doado por Dom Afonso V a Rui Borges, seu provável apoiante em Alfarrobeira, seu antigo almoxarife na alfândega de Lisboa e depois seu conselheiro. Embora não tenha sido possível localizar a doação, averiguou-se que Rui Borges já estava na posse do senhorio em Abril de 1450. A série de senhores de Carvalhais na linhagem Borges ficou bem esclarecida com base na documentação coeva. Verifica-se que a realidade documentada se afasta significativamente dos testemunhos transmitidos pelos antigos nobiliários. Estudou-se, por fim, o percurso social dos Borges até à extinção da varonia, em finais do século XVI. Em particular, estudou-se a ascensão deste ramo dos Borges, as suas alianças matrimoniais e as questões relacionadas com a transmissão ao primogénito e percursos dos restantes filhos. Verifica-se que o percurso dos Borges, senhores de Carvalhais, foi em larga medida um percurso representativo da nobreza senhorial na época.

Post scriptum: Este artigo foi submetido, revisto e aceite entre Novembro de 2016 e Abril de 2017. Em Abril de 2017, veio entretanto a público a monografia Ílhavo: Terra Milenar, coord. Saúl António Gomes, ed. C.M. 
Ílhavo, na qual são transcritos alguns dos principais documentos utilizados no presente artigo. Esta monografia inclui também, da autoria de S.A. Gomes, o capítulo "Ílhavo: entre os Tempos Medievais e o Século XVI", com uma secção sobre os "Senhores de Ílhavo" (p. 154-161). Embora o âmbito seja até certo ponto semelhante, o presente artigo é bastante mais exaustivo e detalhado na recolha de informações e respectiva análise. Por sua vez, "Senhores de Ílhavo" colhe a maior parte da informação genealógica nos antigos nobiliários. O presente artigo diverge assim de "Senhores de Ílhavo" em bastantes pormenores, sobretudo genealógicos e cronológicos. Por limitação de espaço, não é possível enumerar todas as diferenças, mas o leitor interessado poderá facilmente identificá-las. Onde essas diferenças existem, o presente artigo fundamenta devidamente as interpretações seguidas.

Uma das diferenças mais significativas diz respeito à data da confirmação de privilégios aos moradores do senhorio de Carvalhais e Ílhavo feita a pedido de Rui Borges. Gomes (p. 157), baseando-se numa transcrição incompleta, assumiu que dataria de 1449/04/20, mas esta data, sendo anterior à batalha de Alfarrobeira, seria pouco plausível. A transcrição integral utilizada no presente artigo mostra que a confirmação data de 1450/04/20.

"Senhores de Ílhavo" (p. 158) contém alguma informação sobre disputas entre Gonçalo Borges e o mosteiro de Santa Cruz, ocorridas entre 1494 e 1498, as quais, por desconhecimento, não foram referidas no presente trabalho (ANTT, Mosteiro de Santa Cruz de Coimbra, L. 5o dos Autênticos, fl. $60 \mathrm{v}-63$, e L. $1^{\circ}$ dos Autênticos, fl. 127v-128).

\section{Bibliografia}

AHG = Visc. Sanches de Baena, Archivo Heraldico-Genealogico, Typ. Universal, Lisboa, 1872. Alão <1693 = C. Alão de Morais, Pedatura Lusitana (Nobiliário de Famílias de Portugal), A.A.P.M. Vasconcelos, A.A.F. Cruz \& E.E.A.C. Freitas (publ.), Liv. Fernando Machado, Porto, 1943-1948.

BORREGO, N.G. (2003) Cartas de Brasão de Armas: Colectânea, Dislivro Histórica, Lisboa.

CAETANO, P.N.P. (2011) A Burocracia Régia como Veículo para a Titulação Nobiliárquica: o Caso do Dr. João Fernandes da Silveira, dissert. dout., Faculdade de Letras, Porto.

COLAÇO, J.M.T.M. (1929) Cadastro da População do Reino (1527): Actas das Comarcas Damtre Tejo e Odiana e da Beira, Lisboa.

CPDD = Chancelarias Portuguesas. Dom Duarte, Inst. Nac. Investigação Científica, Lisboa, 1998-1999.

CPDJI= Chancelarias Portuguesas. Dom João I, CEH, Univ. Nova de Lisboa, Lisboa, 20042006.

CUNHA, M.S. (2009) "Nobreza, Alianças Matrimoniais e Reprodução Social. Análise comparada dos Grupos Familiares dos Meneses e Cunha (séc. XV - 1640)”, in A.A. Andrade, 
H. Fernandes e J.L. Fontes (coord.), Olhares sobre a História. Estudos oferecidos a Iria Gonçalves, Caleidoscópio, p. 741-786.

CUNHA, M.S., \& N.G. Monteiro (2010) "Aristocracia, Poder e Família em Portugal: Séculos XV-XVIII”, Sociedade, Família e Poder na Península Ibérica, Edições Colibri, Lisboa, pp. 47-75.

Emmenta = A.B. Freire (1907-1908) "Emmenta da Casa da Índia", Boletim da Sociedade de Geografia de Lisboa, 25. a série, 1907, n.o 7, 233-241, n. ${ }^{\circ}$ 8, 265-273, n. ${ }^{\circ}$ 9, 311-319, n.o 10, 331-339, n. ${ }^{\circ} 11,366-375$, n. ${ }^{o} 12$, p. 424-436, e 26. ${ }^{\text {a }}$ série, 1908, n.o 1, p. 18-32.

FARELO, M.S.S. (2008) A Oligarquia Camarária de Lisboa (1325-1433), dissert. dout., Univ. Lisboa.

FIGUEIREDO, D.G. (<1682) Genealogias Portuguesas, Bibl. Nac. Portugal, códices n. ${ }^{\circ} 13125$ (vol. II), 13126 (vol. IV), 13127 (vol. V), 13128 (vol. VII) e 13129 (vol. VIII), provenientes do Arquivo Cadaval, segundo Tarouca, 1946, p. 644.

FONSECA, S. (2007) Ílhavo: Ensaio Monográfico. Séc. X ao Séc. XX, Papiro Editora.

FREIRE, A.B. (1908) "Povoação da Estremadura no XVIo Século", Archivo Historico Portuguez, VI, p. 241-284.

FREIRE, A.B. (1921-1930) Brasões da Sala de Sintra, 3 vols., 2. a edição, Impr. Universidade, Coimbra.

Gayo $<1831$ = M.J.C. Felgueiras Gayo, Nobiliário de Famílias de Portugal, A.A. Meireles e D.A. Afonso (publ.), 10 vols., Braga, 1938-1941.

Góis $\sim 1560$ = Damião de Góis, Livro de Linhagens de Portugal, A.M.F.P. Vasconcelos (intro. e transcr.), Inst. Port. Heráldica, Lisboa, 2014.

Góis $1558=$ Chronica do Sereníssimo Senhor Rei D. Emmanuel escrita por Damião de Goes, Real Imprensa da Universidade, Coimbra, 1790.

GOMES, R.C. (1995) A Corte dos Reis de Portugal no Final da Idade Média, Difel, Lisboa.

GONÇALVES, A.N. (1959) Inventário Artístico de Portugal. Volume VI: Distrito de Aveiro. Zona Sul, Acad. Nac. Belas Artes (ed.), Lisboa.

GUERRA, L.B. (1965) A Casa da Graciosa, Livraria Cruz, Braga.

HENRIQUES, S.P.M. (1721) "Informação de Notícias dadas a Ordem do Illustrissimo Cabido da Cidade de Coimbra”, publ. A.G.R. Madahil, "Informações Paroquiais do Distrito de Aveiro de 1721: Avelãs de Cima”, Arq. Dist. Aveiro, IV, 1938, p. 21-24.

LLRP = Liuro das Linhagens do Reino de Portugal, Biblioteca Nacional de Portugal, códice n. ${ }^{\circ}$ 980. Atribuído a António de Lima (<1582), com material posterior.

LLS16 = A. Machado de Faria, Livro de linhagens do século XVI, Lisboa, 1957.

LOPES, L.S. (2016) “O Verdadeiro Paço de Carvalhais: da História à Reabilitação?”, Jornal da Bairrada, Ano LXV, n. ${ }^{\circ} 2373,2016 / 09 / 01$.

MA = Milenário de Aveiro, A.G. Rocha Madahil, (org.), C.M. Aveiro, 1959.

MADAHIL, A.G.R. (1922) Illiabum. I. Um Projecto de Brasão d'Armas Concelhio, Gráfica Conimbricense, Coimbra.

MADAHIL, A.G.R. (1938) “Forais do Distrito de Aveiro: Foral de Ílhavo", Arq. Dist. Aveiro, IV, p. 179-199. 
Madahil, A.G.R. (1941) "Forais Novos do Distrito de Aveiro: Avelãs de Cima”, Arq. Dist. Aveiro, VII, p. 66-75.

MADAHIL, A.G.R. (1942) "Forais Novos do Distrito de Aveiro: Carvalhais, Ferreiros, Fontemanha e Vale de Avim”, Arq. Dist. Aveiro, VIII, p. 49-58.

Marrocos $=$ Pedro de Azevedo, Documentos das Chancelarias Reais Anteriores a 1531 Relativos a Marrocos, 2 volumes, 1915-1934.

MJA = D.M. Gomes dos Santos (1963-1967) O Mosteiro de Jesus de Aveiro, Est. História (Ultramarina e Continental), Publ. Culturais, n. ${ }^{\circ}$ 65, 2 vols., 5 tomos, Diamang, Lisboa.

MORENO, H.B. (1979-1980) A Batalha de Alfarrobeira, 2 volumes, Coimbra.

PINTO, P. (2014) "Fragmentos de Pergaminho na Torre do Tombo: um Inventário Possível (1315-1683)", Revista de História da Sociedade e da Cultura, 14, 31-84.

PIZARRO, J.A.S. (1987) Os Patronos do Mosteiro de Grijó (Evolução e Estrutura da Família Nobre - Séculos XI a XIV), Porto.

Provas $=$ A.C. Sousa, Provas da História Genealógica da Casa Real Portuguesa, 6 vols., Oficina Silviana, Lisboa Ocidental, 1739-1748.

ROSA, M.L. (1995) O Morgadio em Portugal. Sécs. XIV-XV: Modelos e Práticas do Comportamento Linhagístico, Ed. Estampa.

SANTOS, A.P.F. (1993) "Ferreiros: o Único Concelho Medieval do Distrito de Aveiro", Aqua Nativa, n. ${ }^{\circ}$ 5, Ass. Cultural de Anadia, p. 30-35.

SÃO PAYO, L.M.V. (1987) “Os naturais (Séculos XIII e XIV)”, Raízes e Memórias, n.o 1, Ass. Port. Genealogia, p. 45-71.

Silva $<1705=$ MS. Silva, Nobiliário das Gerações de Entre-Douro-e-Minho, anot. C. Castelo Branco (anot.), M.A. Fernandes (apres. e rev.), 2 vols., Carvalhos de Basto, 2000.

SILVEIRA, J. (1910-1911) “Morgados de Carvalhais”, Jornal de Anadia, 1910/04/02 a 1911/01/12. Republicação: Aqua Nativa, n. ${ }^{\circ}$ 20, Ass. Cult. Anadia, 2001, p. 34-51.

SOUSA, A.C. (1722) “Catálogo dos Bispos das Igrejas de Cabo Verde, S. Thomé e Angola”, Colleç̧am dos Documentos e Memorias da Academia Real da Historia Portuguesa, Lisboa Ocidental.

SOUSA, A.C. (1735-1749) História Genealogica da Casa Real Portugueza, 20 vols., Oficina Silviana.

SOUSA, B.V. (2013) "Afirmação Social e Liderança Nobiliárquica em Portugal (Séculos XIIIXV)", Studia Zamorensia, vol. XII, p. 41-55.

SOVERAL, M.A. (2004) Ascendências Visienses, 2 vols., Porto.

TAROUCA, C.S. (1946) “Os Livros Genealógicos de Diogo Gomes de Figueiredo", Brotéria, vol. 42, p. 643-656.

VASCONCELOS, A.M.F.P. (2012) Nobreza e Ordens Militares: Relações Sociais e de Poder. Séculos XIV a XVI, Militarium Ordinum Analecta, vol. 12, CEPESE, Porto. 